\title{
Iconic Arctic Shipwrecks, Archaeology, and Museum Narratives
}

$<$ running head: Iconic Arctic Shipwrecks, Archaeology, and Museum Narratives

\section{Stephen Wickler}

The Arctic University Museum of Norway, UiT The Arctic University of Norway, Tromsø, Norway. stephen.wickler@uit.no

This article reflects on three Arctic shipwrecks currently being reclaimed for future exhibition. Two are icons of polar exploration. Maud was built for Roald Amundsen's North Pole expedition (19171925) and Belgica was used in the first Antarctic overwintering expedition (1897-1899). The salvage of Maud in Canada and the ship's return to Norway in 2018 was privately financed. Raising Belgica has been the goal of a Belgian non-profit organization. The third is a medieval Norwegian wreck excavated in 2017 with community funding. The role of each ship as icon and archaeological heritage is assessed and framed within a broader discussion of museum narratives.

Key words: Arctic, iconic shipwreck, polar ship, medieval period, museum narratives.

Icon: A person or thing regarded as a representative symbol or as worthy of veneration. (OED); A very famous person or thing considered as representing a set of beliefs or a way of life. (Cambridge Dictionary)

How do shipwrecks become icons and what influence does this have on how they are perceived and handled by stakeholders including archaeologists, museum and heritage management professionals, the general public, and other interested parties? This question will be addressed from the perspective of ships used and wrecked in the Arctic. Three Arctic wrecks currently undergoing a process of recovery through salvage or excavation for the purpose of future exhibition are selected as case studies for comparing and contrasting attitudes towards iconic vessels. The ultimate goal of this exercise is to explore how wrecks take on the role of icons, the degree to which they are viewed as archaeological heritage, and how this effects their anticipated future roles within museum narratives.

Two of the wrecks were ships involved in polar exploration. Maud was built for Roald Amundsen's failed attempt to reach the North Pole (1917-1925) and Belgica was purchased for the first Antarctic overwintering expedition, led by the Belgian Adrien de Gerlache (1897-1899). The ships ended up as hulks in Cambridge Bay, Canada and Harstad, northern Norway, respectively. The third wreck is a late medieval cargo vessel from the small island of Lovund, Norway, excavated in 2017 by maritime archaeologists as a collaborative research project. Each of the vessels is discussed in turn with an appraisal of their life histories afloat and as wrecks, iconic status, treatment as archaeological entities, and potential as active objects in future museum narratives.

\section{The history of Maud and Baymaud}


After navigating the Northwest Passage in Gjøa (1903-1905) and conquering the South Pole in Fram (1911), Norwegian polar explorer Roald Amundsen, who by this point was world famous and a Norwegian icon, set his sights on the North Pole. Although Peary had reached the North Pole first in 1909, Amundsen's goal was to freeze into the ice and drift to the North Pole, as had been attempted by Fridtjof Nansen in Fram (18931896) (Brown, 2012). Due to the poor condition of Fram on return to Norway in 1914, Amundsen had a new polar ship built, this time at Christian Jensen's shipyard at Vollen in Asker. The keel was laid in 1916, and Amundsen named the ship Maud in honour of the Norwegian Queen on 7 June 1917 (Amundsen, 1928). The ship incorporated some of Fram's fittings, including the masts, windlass, helm, and propeller (Wisting, 1930: 47). The Maud expedition marked the start of a new era of polar exploration with its focus on scientific observations under the direction of Harald U. Sverdrup (Drivenes and Jølle, 2006). However, after seven years in the drift ice, the ship had failed to drift anywhere near the North Pole (Fig. 1). Amundsen was plagued by accidents on the expedition. He broke his arm in a fall from the ship, was lightly mauled by a polar bear, and nearly died of carbon monoxide poisoning (Amundsen, 1921, 1928). By 1925, strapped for cash, Amundsen was forced to sell Maud to the Hudson's Bay Company.

Renamed Baymaud and refitted in Vancouver, the ship was used up until 1927 by the Hudson's Bay Company to transport supplies to existing and new company posts in the western Arctic. In 1927, Baymaud sailed to Cambridge Bay (Iqaluktuutiaq), Nunavut, Canada (Fig. 2) with building materials for a new post and remained there, as her deep draught was deemed unsuitable for navigating the shoal waters in the region. The ship was moored close to shore and used as a floating machine shop, warehouse and wireless station (Delgado, 1997: 9-10). In 1930, Baymaud developed a leak and sank at its shallow water moorings. Over the next five years, much of what remained above the waterline was salvaged for building materials or fuel. Some of the ship was used to construct a new Hudson's Bay warehouse. In 1935, the stern hull section was dynamited to remove leaking fuel tanks that the Inuit complained were ruining fishing in the area. By 1939 most of the upper deck was gone (Delgado, 1997: 13-14).

\section{Bringing Maud 'home'}

In 1990, Baymaud was purchased for \$1 from Hudson's Bay Company by Asker municipality, which sought to raise the ship and return it to Vollen, where it was built, to be restored to a floating condition. In 1993, the Asker municipal council received a Canadian Cultural Properties Export Permit for the wreck, but the project was subsequently abandoned due in part to lack of funds (Delgado, 1997: 15-16). In 1995, ownership was transferred to the Tromsø municipal council in northern Norway where a local interest group had launched their own plans to bring Maud 'home' and display the ship resting on the seabed within an exhibition hall at the Polar Museum in Tromsø (Breivoll, 1997). The proposal faced substantial opposition from a variety of sources that included cultural heritage professionals who failed to see the point in honouring a polar expedition that had been a complete failure (Rekvig, 1997). A representative from Tromsø University Museum argued that the wreck represented a valuable cultural heritage resource for the indigenous community in Cambridge Bay and as such should remain in place and protected (Reymert, 1997). Due to 
widespread opposition and a shortage of funds, the proposal was shelved in 1997 and wreck ownership returned to Asker municipality.

Maritime archaeologist James Delgado led site inspection and documentation surveys of the wreck in 1995 and 1996 (Delgado, 1997). He recommended further research and archaeological documentation of the vessel in advance of potential recovery. The necessity of a plan for detailed archaeological involvement in wreck recovery with the participation of a conservator with Arctic experience was also emphasized. Delgado pointed out that the wreck has international significance as cultural heritage and represents an archaeological resource of special interest to both Norway as Maud and Canada as Baymaud.

Maud Returns Home, a project financed by the real estate firm Tandberg Eiendom which had obtained ownership of the wreck in 2011, resurrected the earlier attempt by Asker municipality to salvage and bring the vessel back to Vollen. According to Tandberg Eiendom, their support reflects a general concern for safeguarding local culture historical values (www.maudreturnshome.no/sponsors/). The initial application by the project group in 2011 for an export permit required under the terms of the Canadian Cultural Property Export and Import Act was denied. The federal government decision was based on the determination from an expert appointed by the heritage minister that the wreck represents an object of outstanding significance and national importance and must not be removed (Galloway, 2011). There were also questions about how the wreck would be salvaged and the necessity for additional archaeological documentation. However, an appeal to reverse the decision was successful and the Canadian Review Board issued a permit to Maud Returns Home in 2012. A petition by Cambridge Bay residents to block the permit, based in part on its importance as a tourist attraction, was unsuccessful (Hopper, 2011).

Tandberg Eiendom recruited Asker native Jan Wanggaard to lead the Maud Returns Home project. Wanggaard, a man of many talents ranging from windsurfing champion to industrial designer/product developer and artist (Mathisen, 2018), initiated salvage of the wreck in 2015. Lifting bags were used to raise the hull (Fig. 3), which was placed on a specially modified barge and towed through the Northwest Passage to Greenland in 2017. The final stage of transport took place in 2018 with the arrival of Maud at Vollen on 18 August, 101 years after the vessel was launched. The homecoming was accompanied by a flotilla of boats, a crowd of $c .3000$ waiting on land, and widespread media attention including minute-by-minute coverage by NRK, the Norwegian government-owned television company. Wanggaard's arrival brings to mind associations with the re-enactment ritual 100 years after Amundsen's conquest of the South Pole led by Norwegian ski hero Vegard Ulvang in 2011. Based on the homages he has received (Mathisen, 2018), Wanggaard seems to be undergoing recruitment into the ranks of a uniquely Norwegian 
category of explorer-hero-icon that is inextricably woven into the fabric of national cultural identity. The Norwegian Directorate for Cultural Heritage also expressed admiration for the undertaking by stating that, although a wreck, Maud is authentic and as important as Fram, Gjøa and the Viking ships as a symbol in Norwegian culture history (Staude, 2018). No mention was made of the wreck as archaeological heritage requiring extensive conservation.

\section{Maud as icon and quasi-religious symbol}

The wreck has been portrayed as an icon and a living entity and also appears to be undergoing a form of 'canonization' by the Maud Returns Home project. The following assessment of this ongoing process is based on information gathered from the Maud Returns Home website ( $\underline{\mathrm{MRH}}$, 2018) and other online media sources as well as a published photographic narrative of the project (Wanggaard, 2015). Maud is personified as an iconic presence through the explicit use of human traits and emotions being ascribed to the object itself and the ship's history. Maud Returns Home is presented as a rescue mission to save the old queen of the ice and give her a respectable place to rest in the years to come as illustrated in the following news blog entries from the project website (MRH, 2018):

Ownership of this famous piece of physical history and symbolic object that has suffered in the ice for so long calls for action.

No other concrete initiative exists today to save Maud from slow deterioration, and most people in Canada and Norway support our initiative to build a House of Maud to preserve this historic ship for future generations.

In this way, we wish to give the Maud expedition the status and position in Norwegian culture history that it deserves.

Quasi-religious symbolism is also implicitly employed with references to the resurrection of Maud and construction of a cairn (shrine) in 2012 to commemorate her resting place in Cambridge Bay (Wanggaard, 2015: 44-49).

\section{A home for Maud?}

Maud is to be placed in a specially designed House of Maud conceptualized by Wanggaard as a home rather than museum. Although there is still uncertainty regarding the future display context for the wreck, Tandberg Eiendom commissioned sketches of a Maud museum from two prestigious architect firms in 2011 (Hansen and Sugestad, 2011). Both designs present structures built over the water in a shallow bay at Vollen with one proposal having the appearance of a gleaming temple or shrine approached from shore along a raised walkway. The analogy between this design and a religious structure or pilgrimage site conceived to house a religious relic linked to Roald Amundsen, one of the foremost icons of Norwegian polar exploration, comes readily to mind. A critical objective of Wanggaard's project is the vindication and rehabilitation of Amundsen as a 
polar icon who, in his eyes, has suffered humiliation in the shadow of Fridtjof Nansen. The House of Maud would serve as counterweight to the Fram Museum, a national shrine and memorial museum dedicated to Nansen (Houltz, 2013). Both constitute narratives generated by polar travel fixed on a Norwegian polar hero and his ship. The respective ships are presented as material extensions of a masculine heroic nationalistic narrative and equally worthy of veneration as iconic symbols as the heroes who had them built.

As an artist, Wanggaard views the vessel as an architectural or sculptural entity in contrast to an archaeological approach where wrecks are commonly treated as an assemblage of individual components. Thus, recreating the idea of a ship is more important than documenting and preserving the original parts. Telling Maud's story as a means of honouring Amundsen and his pursuit of scientific knowledge through the expedition is one of Wanggaard's goals. Maud is to be transformed into a home for knowledge, a work of art sculpted by both its builder and Amundsen and further transformed by nature to become the embodiment of Amundsen's lifework. The House of Maud becomes a house-home-space-symbol for knowledge to be interpreted through a museum narrative. Wanggaard's idea of a home for Maud can also be linked to Framheim, the base camp for Amundsen's party on the South Pole expedition.

\section{The polar ship Belgica}

Belgica, which the Belgian Adrien de Gerlache used on the first expedition to overwinter in the Antarctic after being trapped in the pack ice (Fig. 4) (de Gerlache, 1904, 1998), was originally a 36m long barque-rigged steamship and bottlenose whaler named Patria. It was built in Svelvik, Norway, by Johan Christian Jakobsen in 1884. Patria was sold to de Gerlache and renamed Belgica in 1896. In 1896-1897, the ship was refitted and equipped in Sandefjord, Norway, for an Antarctic expedition. Fridtjof Nansen, who was visiting de Gerlache in Sandefjord, and Roald Amundsen met for the first time on Belgica's deck where Amundsen was second mate (not first mate as is often claimed) on the expedition and at the start of his glorious career (Decleir, 1999: 8). This was the first explicitly scientific expedition in the Antarctic after a long period of exploration by whalers and sealers, contrasting with other expeditions that were national initiatives focused on commercial and strategic goals (Arçtowski, 1901). De Gerlache's original plan was to explore the eastern coast of the Antarctic Peninsula during the summer before heading north for the winter and returning for a second summer to explore Victoria Land and attempt to reach the magnetic South Pole. However, Belgica became trapped in the pack ice late in the 1897-1898 season (de Gerlache, 1998; Declair, 1999). Dippel (2018: 12-14) claims that de Gerlache was not steering Belgica so far south for science but had a secret ambition to intentionally freeze into the ice for the winter in order to reach a prime position for sailing 'furthest south' the following summer. 
In 1902, Belgica was sold to Philippe, Duc d'Orléans, and used on expeditions to the Arctic in 1905 and from 1907-1909. In 1916, the vessel was sold and converted to a passenger and cargo ship for transport of coal, serving Spitsbergen from the Norwegian mainland under the name Isfjord. In 1918, it was sold again and renamed Belgica, being converted to a floating cod-liver-oil refinery and fish-processing plant. In 1940, the ship was impounded by British forces and became a hulk used as a floating ammunition depot. On 19 May 1940, the ship was sunk during a German air raid in the small bay of Brurvik on the Gangsåsen peninsula, $2 \mathrm{~km}$ to the north-east of the town of Harstad in Troms County, in Arctic Norway (Fig. 5) (see Kjær,2005 for a detailed account of Belgica's history).

After 50 years resting on the seabed, the wreck of Belgica was rediscovered by recreational divers from Harstad in 1990. An article about the ship and its location by Kjær (2005) generated considerable interest in Belgium, where Belgica is considered a national treasure of the same calibre as Fram and Gjøa in Norway. Following this discovery, the non-profit organization Belgica Societé (Belgica Society) was formed and given ownership of Belgica in 2007. The organization is led by ship owner and maritime entrepreneur Willy Verlsuys and founding members include Belgian academics in the natural sciences, a maritime historian, and maritime archaeologists from the Flemish Heritage Institute (Termote and Cattrijsse, 2006: 3). The New Belgica project was also launched in 2007 and the building of a replica of Belgica begun in Boom, Belgium. A number of factors have substantially delayed construction progress and the replica has yet to be completed (Lunde, 2018).

The Belgica Society originally considered raising the wreck and transporting it to Belgium for conservation and display in its own museum (Termote and Cattrijsse, 2006). As the ship was built more than 100 years ago, it is automatically protected by the Norwegian Cultural Heritage Act of 1978. The Arctic University Museum of Norway has delegated authority for the management of submerged cultural heritage in northern Norway, and has had an advisory role in evaluating plans for raising Belgica since 2006. An inspection trip to Belgium was undertaken by Tromsø University Museum (renamed The Arctic University Museum of Norway in 2019) in 2010 to obtain an overview of activities related to the potential raising of Belgica (Wickler, 2010). The wreck has been evaluated by maritime archaeologists from Belgium and Denmark, including monitoring from 2006-2012 (Termote and Mouchart, 2012) and assessment of ship timber preservation (Gregory et al., 2011). Diving objectives have included an ongoing evaluation of wreck completeness, determining the conservation status of the wooden structure and ship accessories, and documenting potential risks from the cargo of ammunition using sidescan and multibeam sonar, photogrammetry, videos, and hand drawings (Figs 6 and 7). Documentation has shown that the wreck is rapidly 
deteriorating through accelerated wood decay to the point where imminent collapse of the hull is feared due to the continuous pressure of the cargo of munitions and accumulated sediment.

The Belgica Society was recently reorganized as the Belgica Society International based at the Flanders Marine Institute (VLIZ) in Ostend, Belgium (BSI, 2018). The option of complete salvage for Belgica has been ruled out and current plans focus on partial recovery and conservation of important sections of the vessel relevant to the polar expedition. Potential authentic objects worthy of recovery may include the capstan, propeller, rudder, and smaller parts such as the air vent, navigation light, steering gear, and other parts of the superstructure and rigging. Additional inspection of the wreck is planned in order to evaluate potential objects to be raised. One of Belgica's anchors recovered in 1985 by local divers was transported to Belgium in 2007 for exhibition with the New Belgica replica. A second anchor is on display outside the Polar Museum in Tromsø.

\section{Belgica as museum narrative?}

According to their mission statement, the Belgica Society International seeks to honour and promote Belgian maritime heritage and the nation's maritime history through Belgica, an iconic polar ship and tangible relic (BSI, 2018). As is the case with Maud, reference to the wreck as a 'relic' hints at a blurring of the distinction between sacred and profane. In this instance, Belgica becomes the material embodiment of the de Gerlache Antarctic expedition for Belgium and the world. The central role played by Flanders Marine Institute in Belgica Society International suggests that the future exhibition of Belgica (or pieces of the ship) will emphasize the scientific accomplishments of the expedition to a greater extent than glorifying the role of de Gerlache as a polar explorer and national icon. The wreck remains will most likely be housed in close proximity to the future floating replica of Belgica at the port of Ostend, a symbol of Flemish maritime history and the largest city along Belgium's $65 \mathrm{~km}$ coastline.

How will the potential removal of key objects from Belgica effect the interpretive value of the wreck in its current context? Should the retrieval of artefacts associated with the expedition and their relocation to Belgium be viewed as a positive attempt to reclaim what is possible before the impending collapse of the hull and further disintegration of the wreck or a negative impact diminishing its maritime heritage value and integrity? These are key issues that must be addressed by Norwegian cultural heritage authorities when evaluating a potential application from the Belgica Society International for their museum plans.

\section{The Lovund medieval boat}

The Lovund boat was one of only two known medieval shipwrecks in northern Norway at the time of discovery, both located on small offshore islands in Nordland County close to the Arctic Circle (Wickler, 2016). Following destruction of the second wreck by dredging in 1984, it is now the only 
existing medieval vessel to the north of south-western Norway. The wreck was discovered during mechanized sand excavation in 1976 on Lovund, a $4.9 \mathrm{~km}^{2}$ island located $28 \mathrm{~km}$ from the mainland (Fig. 5). The Lovund boat was a clinker-built cargo vessel from the late 15th century, most likely used in the dried cod (stockfish) trade with Bergen in south-western Norway. The oak used to build the boat has been sourced to Agder in southern Norway and dendrochronological dating confirms that it was built from timber felled not long after AD 1441 (Wickler, 2016: 71). With an estimated lifespan of 20-30 years, the vessel would have become a wreck in the late 15 th century.

There has been considerable local interest in excavating and displaying the Lovund wreck since its discovery. Residents of Lovund presented a proposal for excavation with the assistance of recreational divers less than two months after the wreck was discovered. Renewed interest in wreck excavation was expressed by a consortium of five businesses from Lovund who contacted Tromsø University Museum in 1994. In response to this interest, a survey of the wreck-site was undertaken in 1995 as a basis for assessing excavation potential. A budget estimate for excavation and conservation of the wreck was presented to the interest group without any subsequent action being taken (Hesjedal, 1995). A diver-based survey of the wreck site was subsequently undertaken by Tromsø University Museum in 2001 in order to assess the condition of the wreck (Falck and Wickler, 2002). Lovund residents expressed continued interest in excavation and exhibition of the boat by contacting the museum in 2011 and again in 2015. All correspondence and other unpublished documents regarding the Lovund wreck are accessible in the archaeological topographic archive at the Arctic University Museum of Norway. Contact with the Lovund community since 2015 has been formally channelled through a local interest group (Interessegruppa for Lovundbåten) established specifically to support excavation and exhibition of the Lovund wreck. At this point, Tromsø University Museum contacted the Norwegian Maritime Museum in Oslo and a decision was made to collaborate on a research-based study of the wreck financed by the interest group.

\section{Lovund wreck excavation}

Maritime archaeologists from the two museums undertook initial wreck documented in 2016 (Falck et al., 2016). A sea barrier wall enabled the wreck locality to be drained and kept dry with pumps during excavation. The sand layer overlying the wreck was removed mechanically and the main boat timbers exposed by hand excavation to record the extent and construction details of the vessel using digital photogrammetry. The vessel was an open boat $11-12 \mathrm{~m}$ in length with curved stem and straight stern, 12 strakes and 20-22 frames. Evidence of repairs, additional caulking pressed into the planking joints, and a thick tar layer on the lower strakes reveals that the vessel was ageing and leaked. This lends support to a scenario in which the boat was emptied of cargo and intentionally sunk, weighted down by large angular non-ballast rocks still present in the hull. 
Although the boat is not complete, with some parts damaged and others in poor condition, results of the 2016 investigations led to the conclusion that it was possible to conserve, reconstruct, and exhibit the vessel. The Lovund interest group guaranteed financing for complete wreck excavation undertaken in 2017 (Fig. 8), in addition to subsequent digital documentation, conservation, and reconstruction of the vessel for exhibition. Full-scale digital 3D documentation of the individual timbers provided the basis for a recently completed 1:5 scale model. Conservation of the vessel timbers with PEG has been initiated with anticipated completion by the end of 2020 . Following freeze-drying and reconstruction, the vessel should be ready for exhibition by 2022 . The interest group will also finance an architect-designed exhibition building on Lovund for the vessel. If successful, the Lovund vessel will become the first medieval age wreck to be displayed in a Norwegian museum setting.

\section{The Lovund boat interest group}

A majority of both the membership and financial backing for the Lovund interest group originates from the salmon farming industry where locally based Nova Sea AS employs about $28 \%$ of the population of $c .500$ on the island. The company is firmly rooted in the local community, and it has been liberal with profit sharing. The interest group produced a document presenting the historical background, vision, goals, and financing plan for the Lovund boat project most recently updated in 2018 (Interessegruppe for Lovundbåten, 2018). The scientific potential and basis for the project has been emphasized, with excavation, conservation, and reconstruction undertaken by professional archaeologists from the Arctic University Museum of Norway and the Norwegian Maritime Museum (Falck and Wickler, 2017). Permanent exhibition of the reconstructed boat locally is the principal focus and overarching objective of the project. According to the interest group's vision and objectives, the exhibition facility is to be attractive and easily accessible as an arena for cultural and culture historical interpretive activity. It will provide the Lovund community with a new attraction and source of pride. The exhibition will also strengthen the foundation for tourism on the island and in the region and make Lovund a more attractive place to live and work (Interessegruppe for Lovundbåten, 2018).

The role of the Lovund boat as an iconic symbol for the local community is of central importance in the ongoing project to recover and exhibit the wreck. This attitude is illustrated by objections from interest group members to use of the term 'wreck' as being infused with negative connotations that are demeaning and unworthy when referring to such a valued object. For this island community, the Lovund boat is a powerful symbol of pride in bygone golden age when Lovund was part of a far-reaching European maritime trade network. The fact that this small community has the resources to finance excavation and display the vessel is also a source of pride and self-confidence. Furthermore, the Lovund boat performs as a medium for legitimizing recently 
acquired affluence by linking it to a collective past. Some authorities within the regional cultural heritage and museum sector have expressed concern that the proposed museum is not part of the regional museum network, although this status is currently being negotiated. The situation reveals a certain degree of discomfort over use of the Lovund boat to assert local heritage interests outside of a sanctioned system. A key concern for the Lovund interest group is to display the medieval boat in a structure that ensures maximum visibility of the vessel, preferably built out over the inter-tidal zone, as an outward looking architectural window and showcase for the Lovund community. In this respect, it can also be viewed as a worthy place of enshrinement for the iconized remains of a proud past.

As maritime archaeologists and designated experts within the cultural heritage management sector, the main responsibility for the two museums involved is to ensure that the wreck is conserved and reconstructed in a professional and scientifically accurate manner. We have been given a free hand by the interest group to undertake this task in a mutually beneficial and constructive manner. The project also represents a unique opportunity for heritage experts and the local community to work together in shaping an exhibition that satisfies the requirements of heritage preservation while accommodating a local museum narrative. Although viewed as an icon, the community narrative surrounding the Lovund boat contrasts with the heroic narratives of polar exploration at the national level that characterize Maud and Belgica.

\section{Iconic shipwrecks as archaeological heritage}

What are the motivating factors behind the iconization of the shipwrecks discussed here? To what degree have the three wrecks been treated as cultural heritage from an archaeological standpoint? These questions have broader implications for those directly involved in the fields of archaeology, cultural heritage management, and museum studies. In the following section, the individual wrecks are appraised and their relations to one another examined within this framework of enquiry.

\section{Wrecks as icons}

A common thread for Maud and Belgica as polar exploration vessels is that both can be seen as failures, with Maud failing to reach the North Pole and Belgica ending up stranded in the Antarctic pack ice rather than reaching Victoria Land as was intended. But 'there's no success like failure' (Dylan, 1965), and both expeditions have been elevated to the level of heroic ventures with the ships being iconized as material extensions of the icons of polar exploration Roald Amundsen and Adrien de Gerlache.

The question of who owns the past, a central concern within debates on the politics of cultural heritage and archaeology (Smith, 2004, 2006), is pertinent in the case of Maud where there are contrasting Canadian and Norwegian perceptions of the wreck as heritage. While Maud Returns Home and the Norwegian media consistently refer to the ship as Maud, Canadian media see the 
wreck as Baymaud, although some acknowledge that it is a ship also known as Maud to Norwegians. A number of Canadian newspaper articles concerning Maud Returns Home also state that Amundsen abandoned Maud in 1925, which, although not completely accurate, does reflect Amundsen's attitude towards the expedition at this stage. These contrasting viewpoints underscore the importance of the ship as an internationally significant cultural resource and archaeological site as both Maud and Baymaud. The fact that Canada finally granted an export permit for the wreck reveals inherent weaknesses in the existing framework for safeguarding Canadian cultural heritage. Belgica is also internationally significant with respect to the multinational crew on de Gerlache's expedition, which included Roald Amundsen, Henryk Arçtowski a Polish geologist, oceanographer, and meteorologist, and Romanian biologist Emil Racoviţă, who were all to gain international renown as explorers or scientists. The wreck has received particular attention in Romania where Racoviță is a highly esteemed national figure. The general lack of knowledge and interest regarding the wreck in the Harstad region and Norway in general stands in stark contrast to its iconic status in Belgium.

The impetus for the iconization of the Lovund boat is grounded in the local community and lies at the opposite end of the spectrum from the two iconic ships of polar exploration that are symbols of national self-esteem and heroic memorialization. It also raises issues relevant to community-based archaeology (Smith and Waterton, 2009; Atalay, 2012); for example, the iconization of polar ships at the national level has tended to be disengaged from local interests and serves as a conduit for expressing narratives that exist unaltered since the golden age of polar exploration. However, all three icons reflect identities shaped by the negotiation and presentation of selected knowledge. Although the iconic status of the Lovund boat among local residents is an expression of community identity rather than national pride, it does represent an attempt to assert independence and self-determination highlighting the importance of Lovund within a regional and superregional context.

\section{Wrecks as archaeology}

There is a notable contrast between the salvage of Maud, where no archaeologists have been involved beyond Delgado's preliminary survey, and the other two wrecks where archaeological documentation has been a priority and the author is directly engaged as a maritime archaeologist and cultural heritage expert. In the case of Maud, Delgado (1997) strongly recommended archaeological participation as a necessary component of wreck recovery and it was stipulated that additional archaeological documentation had to be undertaken to obtain an export permit. These recommendations were apparently ignored or bypassed, as Maud Returns Home was able to obtain a permit for salvage without an archaeological assessment. In a lecture by Jan Wanggaard attended by the author (Wanggaard, pers. comm.), it was explained how the wreck had been 'cleaned up' 
after being raised to make it lighter and easier to transport by removing loose objects and storing some in shipping containers to be sent back to Norway. A plan for analysis and conservation of the objects that have been displaced from their archaeological context has yet to be formulated. It also remains to be seen how the wreck itself will be conserved in Norway. It is noteworthy that if Maud had sunk in Norway, an application for dispensation from the Cultural Heritage Act as an automatically protected vessel built more than 100 years ago would now be necessary.

The Belgica Society's plans to raise Belgica have involved highly qualified Belgian and Scandinavian maritime archaeologists from the start, in full compliance with Norwegian legal requirements for the protection of cultural heritage. Archaeological evaluation of the wreck has also resulted in collaborative research related to wood preservation and other issues of considerable value to heritage management. Although initiated and financed by a local interest group, professional archaeologists have had full control of ongoing recovery and conservation of the Lovund boat through a unique collaborative research project guided by an explicit research design. The project has also been characterized by respectful dialogue and cooperation between archaeologists and local residents.

\section{Shipwrecks and museum narratives}

Shipwrecks have a long history of fascinating and engaging the public and lend themselves readily to iconization. These factors come into play when linking wreck recovery to plans for subsequent display as exemplified by the three Arctic shipwrecks addressed here. However, the true purpose of these future exhibitions may not be readily decipherable when cloaked in rhetoric employed to justify wreck recovery. Plans for future display of the vessels embraces much more than building a structure to house an object. Disentangling the tightly interwoven roles of wreck exhibition as shrine, memorial, and museum narrative is a challenge requiring a critical analytical approach. The following discussion considers the three shipwrecks within a broader treatment of relevant museum narrative themes.

\section{Polar ship biographies and authenticity}

Selecting a single phase from the complex history of a polar vessel for iconization in support of a heroic narrative detracts from the rich, layered storytelling potential of an individual ship. Mathisen's (2012) analysis of Polstjerna, a polar ship from 1949 currently exhibited on land as part of the Arctic University Museum of Norway, argues that its original function as a herring boat has been bypassed in favour of a museum narrative emphasizing later use as a seal hunting ship explicitly linked to a heroic national narrative of polar exploration. Mathisen rightly asserts that tempering the heroic with the mundane would have enabled a more balanced, truthful museum narrative. This criticism is also applicable to both Maud and Belgica, and in both cases it can be argued that recognizing each phase of their histories would enrich future museum narratives. 
Furthermore, polar ship and boat biographies provide a bridge between the diverse cultural and ethnic groups that have used these complex, multivocal objects. The rigid classification of vessels into mutually exclusive categories defined by cultural parameters, ethnicity, and function is a problem for nautical archaeology and related museum narratives that deserves increased scholarly attention. Important details of a vessel's life are lost in the process of 'cleaning up', as in the case of Maud, since the ability for a ship to speak in a museum narrative is inextricably bound to documentation principles and methodology.

Which phase(s) of a ship biography are selected as authentic? This is a concern that has proved to be problematic for Maud and Belgica and raises the question of how authenticity has been employed as a key element in assigning value to historical objects. Although authenticity is a contested and controversial concept, it remains a significant means of analysing and critiquing encounters with 'the past' (Kidd, 2011; Silverman, 2015). Unfortunately, it has also been used as a political tool to legitimize decision making by the heritage management community in a way that avoids coming to terms with the complexities of nautical heritage.

\section{Ships and nationalist ideology}

The ship has always had been imbued with a strong symbolic value that continues to be expressed through religion and mythology in contemporary museum contexts. Cederlund (1997) has explored linkages between ship archaeology and nationalism and how these are expressed in national museums within Scandinavia. He asserts that Swedish royal shipwrecks from the 16 th and 17 th centuries such as Vasa have been employed as a state sponsored ideological tool coloured by symbolism with ship salvage endorsed as a nationalistic ritual. Viking ships play a similar role as museological expressions of national ideology at the Viking ship museums in Oslo, Norway and Roskilde, Denmark. The strength of these museum narratives is illustrated by the fact that the Vasa Museum in Stockholm (c.1.5 million visitors) (https://www.vasamuseet.se/en/vasa-history/timeline) and Viking Ship Museum in Oslo (c.500,000 visitors) (https://standbynordic.com/norways-mostpopular-exhibits-may-collapse/) are currently the most visited museums in their respective countries.

The Viking Ship Museum is also one component of an ideological ship museum complex on the island of Bygdøy in Oslo that includes the Norwegian Maritime Museum, the Kon-Tiki Museum, and the Fram Museum, Norway's official shrine to polar exploration and home of the iconic polar ships Fram and Gjøa. Fram's status has been elevated by its association with Amundsen and others as the embodiment of Norwegian national character and a direct descendant of the iconic Viking ship Ormen Lange, linking Norway as a seafaring nation back to the Viking Age (Houltz, 2010, 2013). The Fram Museum building, known as 'Saga', was constructed as a 
memorial temple with architectural allusions to Viking houses and medieval churches (Houltz, 2013).

\section{Ships, art, and science in museum narratives}

Achieving a balance within the museological triangle of expert, museum public, and object is a challenging topic of longstanding scholarly debate (Whitcomb, 2003; Smith, 2006; Simon, 2007). A central concern is the degree to which experts should define museum parameters by dictating narrowly defined professional and scientific criteria. Integrating heritage and museum studies is a related problem requiring active mediation (Darko, 2016). These are critical factors for ensuring that future museum treatment will preserve existing knowledge and transmit knowledge in a creative fashion to all stakeholders. Balancing the role of experts with reconstruction and interpretation for the public has also been increasingly discussed within maritime museum archaeology (Bigourdan et al., 2016; Buchanan, 2016). The relative importance of art and science in the process of generating and transmitting knowledge is germane to the present discussion of iconic shipwrecks. Relevant questions include how scientific value is ascribed to objects and collections as a whole and whether this is a desirable goal. It is also appropriate to ask what constitutes a scientific collection and why collections should be incorporated into a formal museum model as opposed to alternative display options, such as experience centre, home, or shrine.

Is it possible to synthesize the artistic vision of Wanggaard for a House of Maud with a concern for the scientific value of the wreck as an archaeological object? Perhaps the exhibition of Maud can be visualized as an attempt to cultivate potential synergic relations between a museum and attraction or experience centre, as Mathisen (2011) has suggested. How might objects from Belgica be used to promote the scientific accomplishments of the de Gerlache expedition without being treated as relics in support of a Belgian nationalistic narrative of polar exploration? In the case of the Lovund boat, it would be wise for us as archaeologists to avoid dictating exhibition parameters from a potentially narrow and short-sighted cultural heritage management perspective.

\section{Conclusion}

What are the lessons to be learned from the three iconic Arctic shipwrecks? A significant motivation for taking a closer look at these ships was personal involvement with Belgica and the Lovund boat as a maritime archaeologist with delegated responsibility for the management of nautical heritage in Arctic Norway. The striking parallels between the manner in which Maud has been embraced as an iconic symbol and attitudes towards the other two wrecks, albeit from quite different standpoints, were also a motivating factor. National media attention generated by the ritual act of bringing Maud 'home' and its role in reinforcing Norwegian self-esteem is intriguing when juxtaposed with the treatment of the other two wrecks. 
Results of the comparative exercise undertaken here have revealed the power of iconization in shaping attitudes and emotions towards a shared nautical past. This ascribed status also has major implications for how wrecks may perform within museum narratives. Those who have been instrumental in shaping an iconic status also envision each wreck within the context of a proposed exhibition. The possibility of evaluating potential future trajectories for display, interpretation, and narrative presents a challenging and dynamic alternative to the analysis of existing ship narratives. The potential for integrating creative and scientific visions of museum narratives can be particularly stimulating. Envisioning a House of Maud as a home for a sculptural expression is a radical departure from viewing Maud as an eviscerated hull with diminished archaeological significance as a consequence of salvage procedures. It is also necessary to acknowledge that Wanggaard's artistic perspective is more in tune with that of the public who see the wreck as a symbolic architectural expression. The Lovund boat holds out a unique opportunity for reaching a consensus between heritage experts and the local community in shaping a future exhibition narrative. In conclusion, the three Arctic ships demonstrate that there is no single 'right' way of doing things when it comes to interpreting nautical heritage, but that it remains essential to base our interpretations on high-quality archaeological documentation.

\section{Acknowledgements}

A shorter version of this paper was presented at the Heritage 2018 conference in Granada, Spain. I wish to acknowledge the central role of Tori Falck and other colleagues at the Norwegian Maritime Museum in the ongoing Lovund research project and to the Lovund boat interest group for their financial support and encouragement. Thanks to Marnix Pieters, research director of archaeology at the Flanders Heritage Agency, for providing images of Belgica and to Jan Wanggaard for his photograph of Maud, with reference made to a lecture he gave 'Maud kommer hjem' on 14 February 2018 at a meeting held by the Arktisk Forening at the Polar Museum, Tromsø, Norway. Thanks also to Rossella Ragazzi and Mariann Mathisen for constructive comments on the manuscript.

\section{References}

Amundsen, R., 1921, Nordostpassagen: Maudferden langs Asiens kyst 1918-1920. Kristiania: Gyldendalske Boghandle.

Amundsen, R., 1928, My Life as an Explorer. Garden City, New York: Doubleday, Doran and Company.

Arçtowski, H., 1901, The Antarctic voyage of the 'Belgica' during the years 1897, 1898, and 1899.

The Geographical Journal 18.4: 353-390. 
Atalay, S., 2012, Community-based Archaeology: Research with, by, and for Indigenous and Local Communities. Berkeley: University of California Press.

BSI (Belgica Society International), 2018, https://www.belgica-society-international.org/ (accessed 22 November 2018).

Bigourdan, N., Edwards, K. and McCarthy, M., 2016, Steamships to suffragettes: a case study of interpretative museology, public engagement, and digital development. Museum Worlds: Advances in Research 4, 138-154.

Breivoll, J.D., 1997, Polarskuta 'Maud' til Tromsø. Nordlys, 1 March 1997, 36-37.

Brown, S.R., 2012, The Last Viking: The Life of Roald Amundsen. New York: Da Capo.

Buchanan, S.A., 2016, Curation as public scholarship: museum archaeology in a seventeenthcentury shipwreck exhibit. Museum Worlds: Advances in Research 4, 155-166.

Cederlund, C.O., 1997, Nationalism eller vetenskap? Svensk marinarkeologi i ideologisk belysning. Stockholm: Carlsson.

Darko, B., 2016, Bridging the boundaries between museum and heritage studies. Museum International 68.1-2, 15-28.

Decleir, H. (ed.), 1999, Roald Amundsen's Belgica Diary. The first scientific expedition to the Antarctic. Bluntisham, England: Bluntisham Books.

De Gerlache, A., 1904, The Belgian Antarctic Expedition under the Command of A. de Gerlache de Gomery. Brussels: Gomery Hayez.

De Gerlache, A., 1998, Fifteen Months in the Antarctic (translated by M. Raraty). Norfolk: Bluntisham.

Delgado, J.P., 1997, Made for the Ice: A report on the wreck of the Hudson's Bay Company ship BayMaud, ex-polarskibet Maud. Vancouver: Vancouver Maritime Museum and Underwater Archaeological Society of British Columbia.

Dippel, J.V.H., 2018, To the Ends of the Earth: The Truth Behind the Glory of Polar Exploration. New York: Prometheus Books.

Drivenes, E-A. and Jølle, H.D. (eds), 2006, Into the Ice: The History of Norway and the Polar Regions. Oslo: Gylendal Akademisk.

Dylan, B., 1965, Love minus zero / no limits. Bringing It All Back Home. New York: Columbia Recording Studios.

Falck, T. and Wickler, S., 2002, Lovundvraket. Mellomaldervraket på Lovund, Lurøy kommune, Nordland fylke. Rapport etter befaring juni 2001. Unpublished report, topographic archive, The Arctic University Museum of Norway. 
Falck, T. and Wickler, S., 2017, Prosjektplan: arkeologisk utgravning, dokumentasjon, rekonstruksjon og konservering av Lovundbåten, AID. 95292. Unpublished ms., The Arctic University Museum of Norway and Norwegian Maritime Museum.

Falck, T., Wickler, S. and Ahrens, S., 2016, Rapport. Lovundbåten. Norsk Maritimt Museum Arkeologisk rapport 2016:2.

Galloway, G., 2011, Ottowa denies Norwegians passage for Maud. The Globe and Mail, 16 December 2011.

Gregory, D., Jensen, P., Strætkvern, K., Lenarts, T. and Pieters, M., 2011, A preliminary assessment of the state of preservation of the wreck of the Belgica. Relicta 7, 145-162.

Hansen, A.H. and Saugestad, K., 2011, Slik kan Maud-museet i Asker bli. Norwegian Public Broadcasting Company (NRK) Ostlandsendingen 15 April 2011.

Hesjedal, A., 1995, Kommentarer og budsjettforslag til utgravning av middelalderbåtvrak på Lovunden, Lurøy kommune. Unpublished report, topographic archive, The Arctic University Museum of Norway.

Hopper, T., 2011, Norway, Nunavut clash over shipwreck. The Globe and Mail, 7 August 2011. Houltz, A., 2010, Captives of narrative: Scandinavian museum exhibits and polar ambitions. Culture Unbound 2, 719-744.

Houltz, A., 2013, Displaying the Polar Nation: Nordic museum exhibits and Polar ambitions, in Sörlin, S. (ed.), Science, Geopolitics and Culture in the Polar Region: Norden Beyond Borders, 293-327. London and New York: Routledge.

Interessegruppe for Lovundbåten, 2018, Prosjekt Lovundbåten: projekthistorikk, visjon og målsetting, budsjetter og finansieringsplan. Unpublished ms., Lovund Boat Interest Group.

Kidd, J., 2011, Performing the knowing archive: heritage performance and authenticity. International Journal of Heritage Studies 17.1, 22-35.

Kjær, K.G., 2005, Belgica in the Arctic. Polar Record 41.218, 205-214.

Lunde, S.T., 2018, Den norske polarskute 'Belgica' bygges i Belgia. Kysten 2, 18-25.

Mathisen, M., 2011, Men Maud var ikke død. 18 March 2011 https://forskning.no/content/menMaud-var-ikke-dod (accessed 22 November 2018).

Mathisen, M., 2012, Med M/S Polstjerna til vanns og til lands - og på museum: narrasjon, materialitet og nettverksrelasjoner. in A. Maurstad and M. Hauan (eds) Museologi på norsk: universitetsmuseenes gjøren, 141-168. Trondheim: Akademika forlag.

Mathisen, M., 2018, En dronning verdig. Kysten 5, 24-29.

MRH (Maud Returns Home), 2018, http://www.maudreturnshome.no/ (accessed 22 November 2018).

Rekvig, O.P., 1997, Maud-saken - en kommentar. Nordlys, 5 March 1997, 32. 
Reymert, P.K., 1997, 'Maud' - et pluss for polarbyen Tromsø? Nordlys, 1 March 1997, 37.

Silverman, H., 2015, Heritage and authenticity, in E. Waterton and S. Watson (eds), The Palgrave Handbook of Contemporary Heritage Research, 69-88. London: Palgrave Macmillan.

Simon, J.K., 2007, Museums in the Material World. London and New York: Routledge.

Smith, L., 2004, Archaeological Theory and the Politics of Cultural Heritage. London and New York: Routledge.

Smith, L., 2006. The Use of Heritage. London and New York: Routledge.

Smith, L. and Waterton, E., 2009, Heritage, Communities and Archaeology. London: Duckworth, Duckworth Debates in Archaeology Series.

Staude, T., 2018, Skuta som vant over polarisen — til slutt. Norwegian Public Broadcasting Company (NRK) 20 August 2018. https://www.nrk.no/kultur/polarskuta-_maud_-vant-overpolarisen- -til-slutt-1.14142662 (accessed 22 November 2018).

Termote, T. and Cattrijsse, A., 2006, Raising the Belgica: a report on the visit to Norway by the Belgica Society, 19-23 August 2006. Unpublished Belgica Society report.

Termote, T. and Mouchart, N., 2012, The Belgica: the site and its condition, March 2012. Unpublished report to the Belgica Society.

Wanggaard, J., 2015, Maud Returns Home 2011-2015. Tandberg Eiendom AS.

Whitcomb, A., 2003, Re-imagining the Museum: Beyond the Mausoleum. London: Routledge.

Wickler, S., 2010, Raising the Belgica? Report from an inspection trip to Belgium, October 18-21, 2010. Unpublished report, Tromsø University Museum.

Wickler, S., 2016, Medieval shipwrecks from North Norway and their contribution to understanding maritime interaction and trade. IJNA 45.1, 59-76.

Wisting, O., 1930, 16 år med Roald Amundsen. Fra pol til pol. Oslo: Gyldendal Norsk Forlag.

\section{Captions}

Figure 1. The Polar ship Maud in the ice (unknown photographer, National Library of Norway).

Figure 2. Map of Arctic Canada showing the location of Cambridge Bay (Adnan Icagic, The Arctic University Museum of Norway).

Figure 3. Bow view of Maud / Baymaud in Cambridge Bay awaiting transport in 2017 (Jan Wanggaard (CMaud Returns Home).

Figure 4. Belgica trapped in the ice during the Belgian Antarctic Expedition (1897-1899)

(Frederick Cook, Wikimedia Commons).

Figure 5. Map of northern Norway showing the location of Belgica and the Lovund boat (Adnan Icagic, The Arctic University Museum of Norway). 
Figure 6. Diver inspecting the wreck of Belgica (Nicolas Mouchart CFlanders Heritage Agency). Figure 7. Photomosaic of Belgica in 2008 (Nicolas Mouchart CFlanders Heritage Agency).

Figure 8. Photograph of the Lovund boat viewed from the stern during excavation in 2017 (Stephen Wickler, The Arctic University Museum of Norway). 


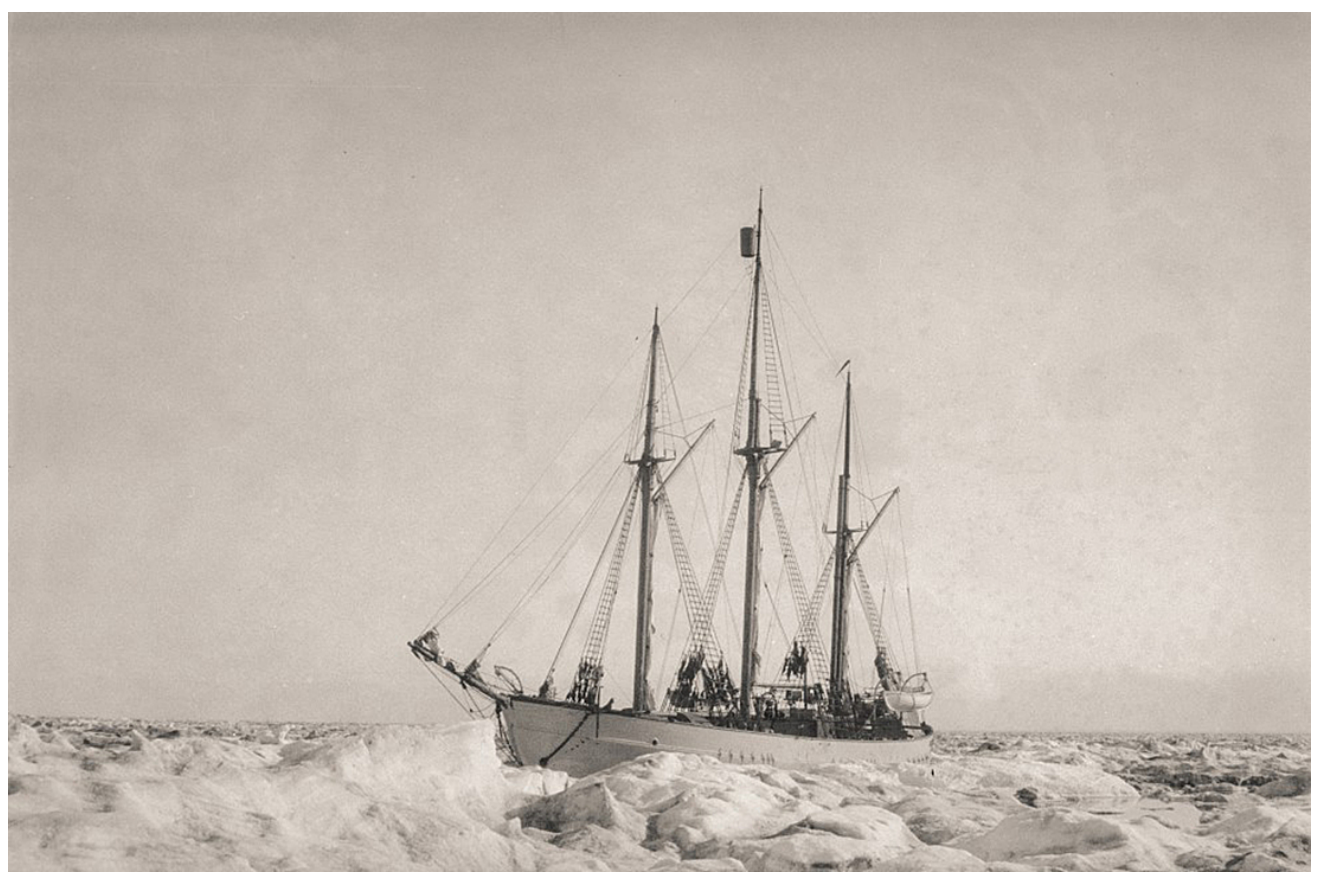

The polar ship Maud in the ice 


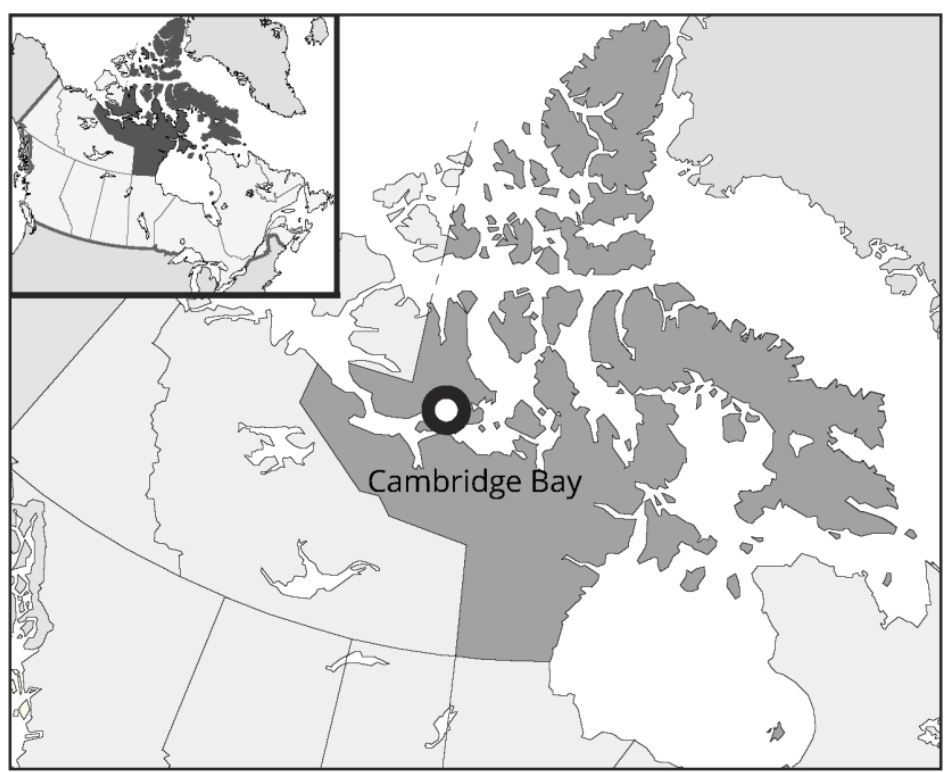

Map of Arctic Canada showing the location of Cambridge Bay. Adnan Icagic, Tromsø University Museum. $180 \times 280 \mathrm{~mm}(200 \times 200 \mathrm{DPI})$ 


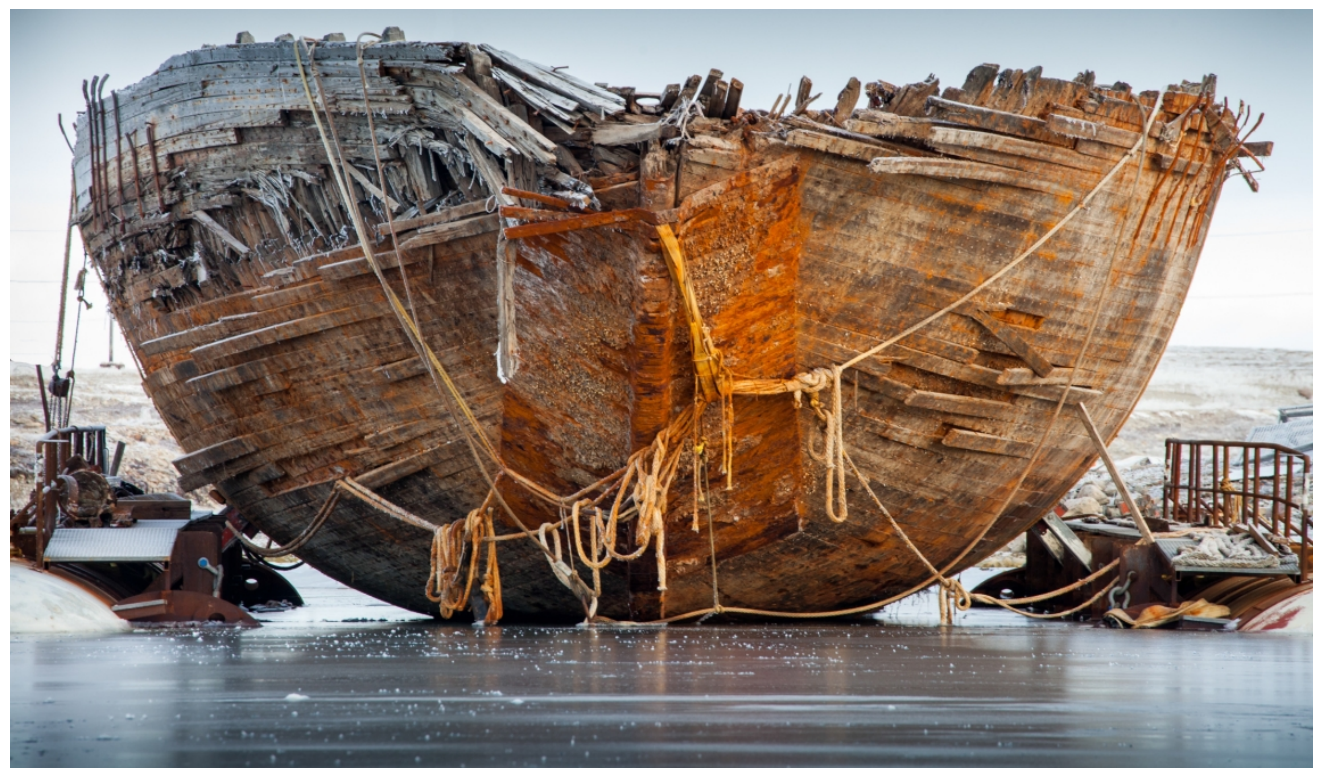

Bow view of Maud / Baymaud in Cambridge Bay awaiting transport in 2017. Jan Wanggaard @Maud Returns Home.

$338 \times 197 \mathrm{~mm}(164 \times 164 \mathrm{DPI})$ 


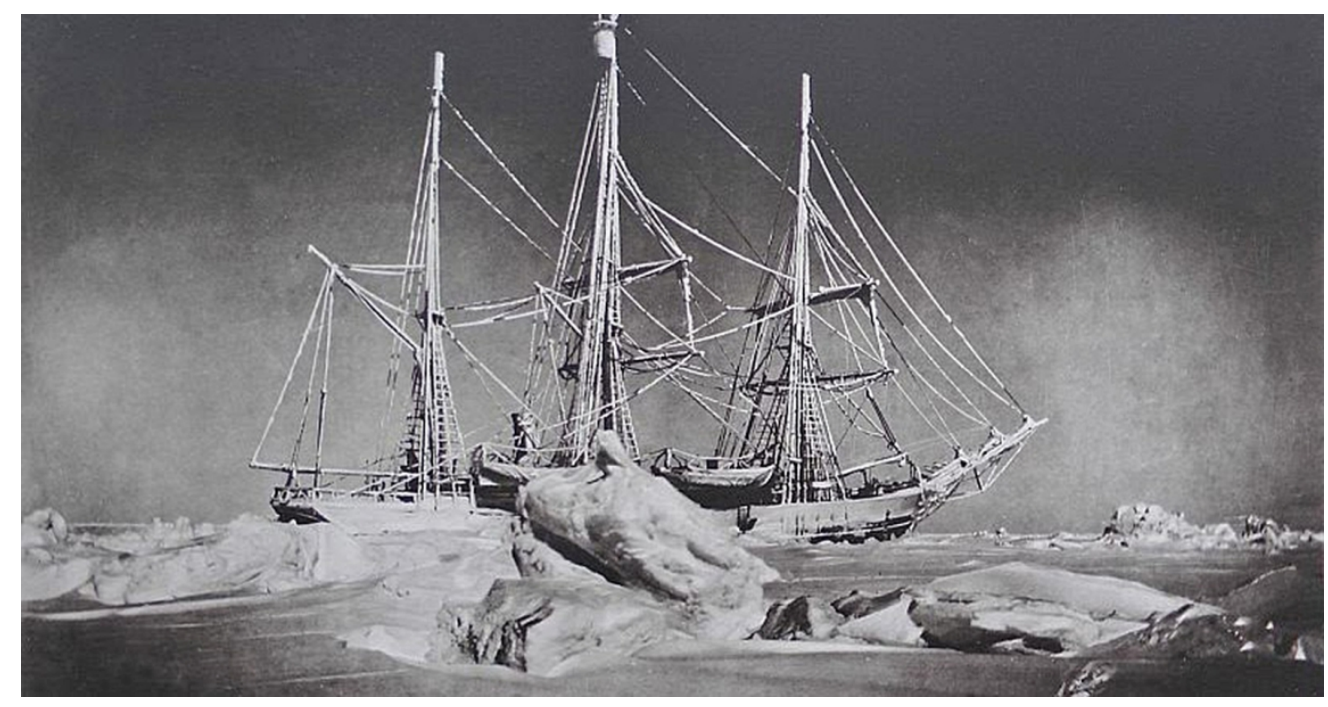

Belgica trapped in the ice during the Belgian Antarctic Expedition (1897-1899). 


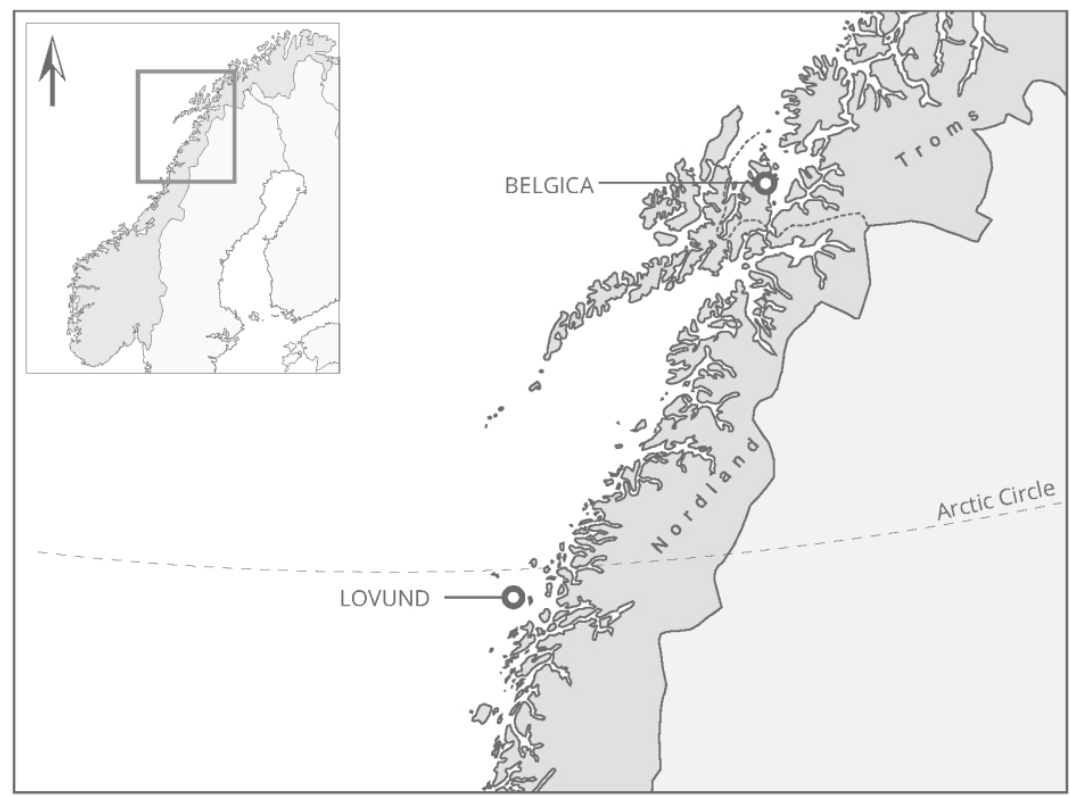

Map of northern Norway showing the location of Belgica and the Lovund boat. Adnan Icagic, Tromsø University Museum. 


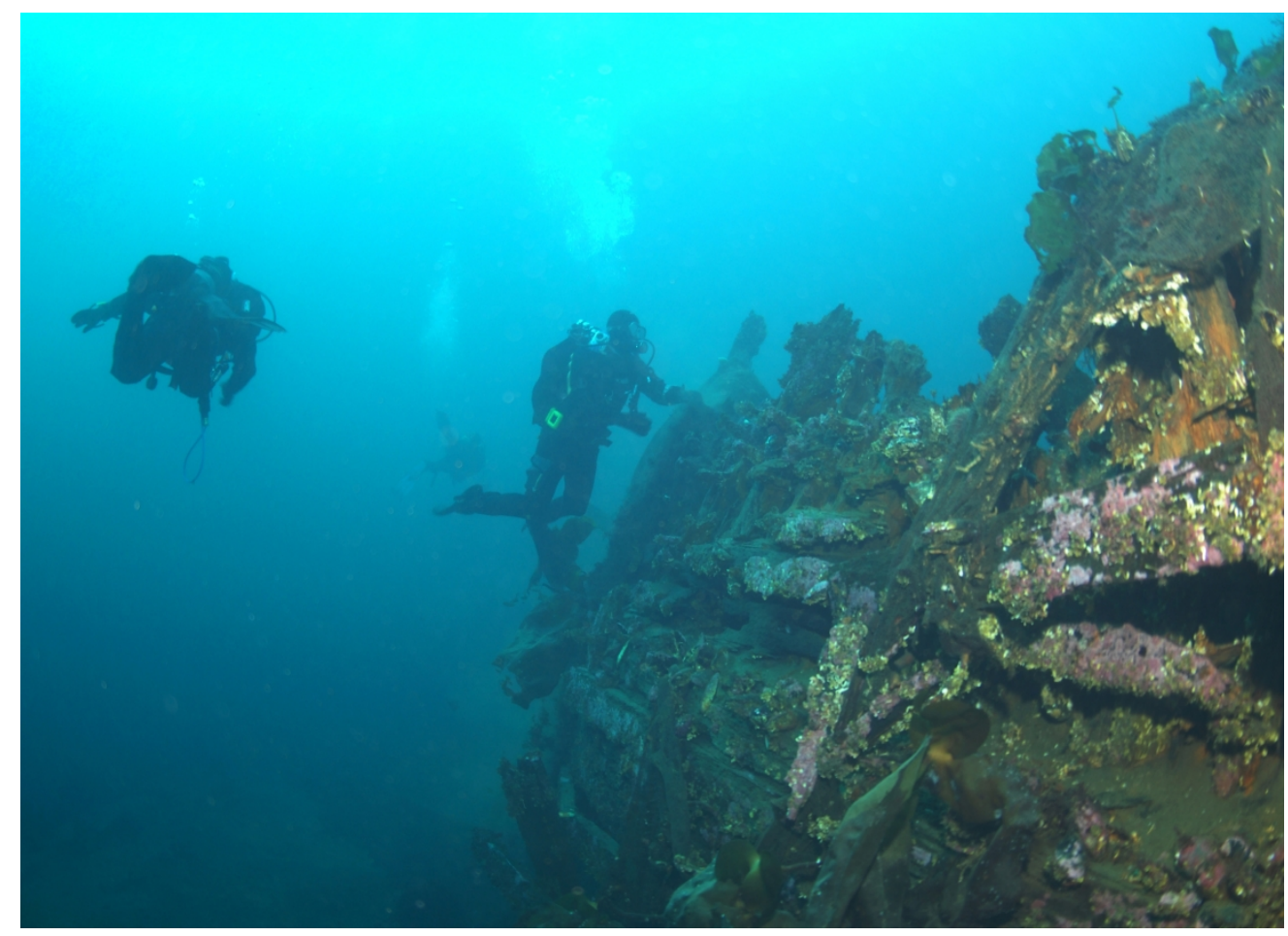

Diver inspecting the wreck of Belgica. Nicolas Mouchart (CFlanders Heritage Agency. $289 \times 209 \mathrm{~mm}(300 \times 300$ DPI $)$ 


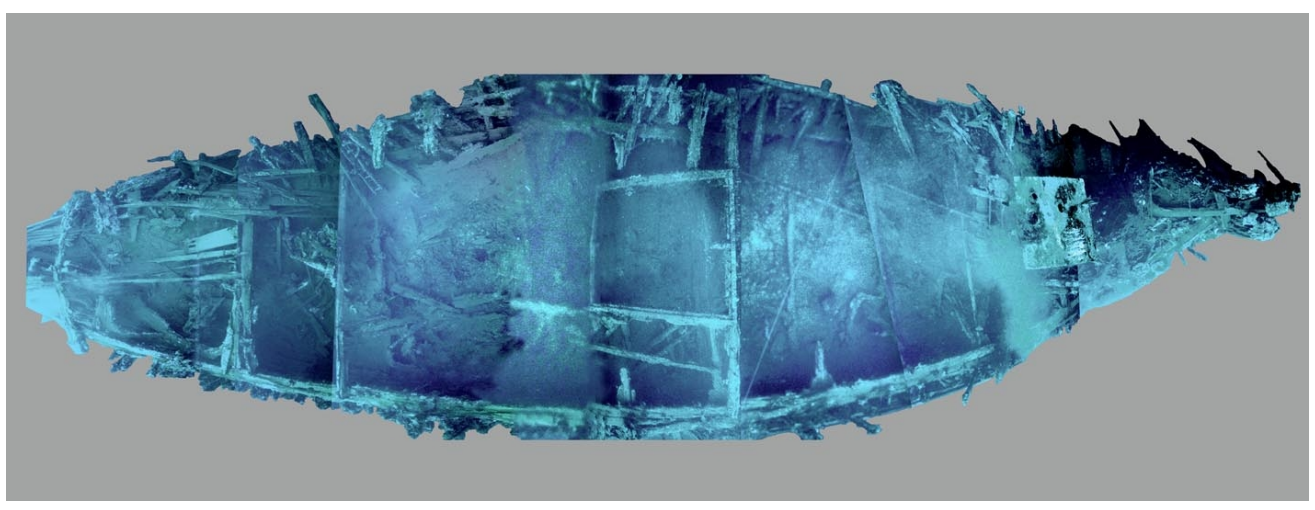

Photomosaic of Belgica in 2008. Nicolas Mouchart @Flanders Heritage Agency. $499 \times 187 \mathrm{~mm}(72 \times 72 \mathrm{DPI})$ 


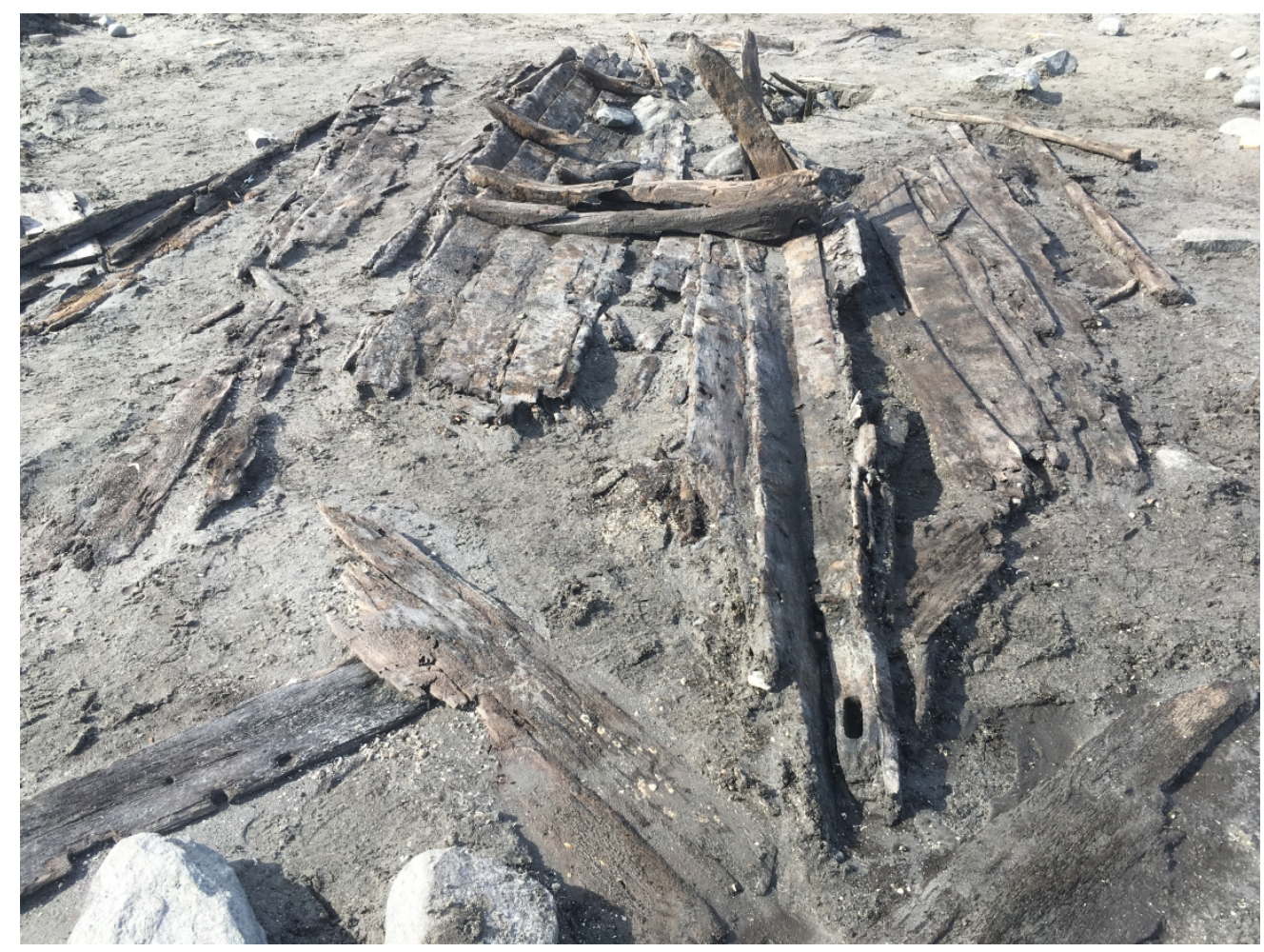

Photograph of the Lovund boat viewed from the stern during excavation in 2017. Stephen Wickler, Troms $\varnothing$ University Museum. 